\title{
Recurrent PALB2 mutations and the risk of cancers of bladder or kidney in Polish population
}

\author{
Elżbieta Złowocka-Perłowska ${ }^{1 *}$, Tadeusz Dębniak1, Marcin Słojewski², Artur Lemiński ${ }^{2}$, Michał Soczawa², \\ Thierry van de Wetering ${ }^{3}$, Joanna Trubicka ${ }^{4}$, Wojciech Kluźniak', Dominika Wokołorczyk ${ }^{1}$, Cezary Cybulski ${ }^{1}$ and \\ Jan Lubiński ${ }^{1}$
}

Introduction: The role of PALB2 in carcinogenesis remains to be clarified. Our main goal was to determine the prevalence of PALB2 (509_510delGA and 172_175delTTGT) mutations in bladder and kidney cancer patients from Polish population.

Materials and methods: 1413 patients with bladder and 810 cases with kidney cancer and 4702 controls were genotyped for two PALB2 variants: 509_510delGA and 172_175delTTGT.

Results: Two mutations of PALB2 gene were detected in 5 of $1413(0.35 \%)$ unselected bladder cases and in 10 of 4702 controls (odds ratio [OR], 1.7; 95\% Cl 0.56-4.88; $p=0.52$ ). Among 810 unselected kidney cancer cases two PALB2 mutations were reported in two patients (0,24\%) (odds ratio [OR], (OR=1.2; 95\% Cl 0.25-5.13; $p=0.84)$. In cases with mutations in PALB2 gene cancer family history was negative.

Conclusion: We found no difference in the prevalence of recurrent PALB2 mutations between cases and healthy controls. The mutations in PALB2 gene seem not to play a major role in bladder and kidney cancer development in Polish patients.

Keywords: 509_510delGA, 172_175delTTGT mutation, PALB2, Survival

\section{Introduction}

Carcinogenesis is an intricate multi-step process initiated by abnormal oncogenic signals in different signaling pathways. Defects in DNA repair are responsible for many cancers like: bladder, prostate, breast, kidney, colorectal, pancreatic, ovarian. The mismatch repair (MMR) and homologous recombination (HR) are well-established DNA repair pathways with links to human cancer [1-7]. In the homologous recombination DNA damage repair a key role play the genes $B R C A 1$ and $B R C A 2$ which interacts with many proteins: proteins of the MNR complex

\footnotetext{
*Correspondence: elzunik@wp.pl

'Department of Genetics and Pathology, International Hereditary Cancer Center, Pomeranian Medical University in Szczecin, Unii Lubelskiej 1, 71-252 Szczecin, Poland

Full list of author information is available at the end of the article
}

(MRE11/RAD50/ NBS1), RAD51, CtIP, MRE11, ATM, H2AX, PALB2, RPA, RAD52 and the Fanconi anemia proteins [8]. Mutations in genes: PALB2, ATM, RAD50, $M R E 11, N B N$ and the genes for the MRN complex are responsible for hereditary cancers. PALB2 has a large number of interactions with DNA damage response proteins BRCA1, BRCA2, RAD51, RAD51C and XRCC3 which play function in DNA repair by homologous recombination $[9,10] . P A L B 2$ is not only partner and localizer of $B R C A 2$ but also is localized and interacts with $B R C A 1$ plays an important role as a pivotal tumor suppressor protein [11]. Mono-allelic PALB2 germline mutations disrupt the interaction of PALB2 with either BRCA1 or BRCA2 engender DNA damage sensitivity, HR defects, and cancer susceptibility to breast, ovarian, pancreatic whereas biallelic PALB2 germline mutations cause Fanconi anemia 
subtype FANCN, with early onset of acute myeloid leukemia, medulloblastoma, neuroblastoma and often Wilms' tumor [12-17]. Given the intimate functional links between PALB2 and BRCA2 and the similar phenotypes associated with biallelic mutations in the genes that encode them, it is plausible that monoallelic PALB2 mutations confer susceptibility to adult cancer [12].

In Finland, Canada (in French-Canadians), and Poland, mutations in PALB2 are the cause of between 0,5 and $1 \%$ of all breast cancers and $0,52 \%$ unselected cases of pancreatic cancer $[13,18-20]$. We were interested to investigated if mutations in PALB2 genes could be relevant to the pathogenesis of bladder or kidney cancer. Herein we genotyped 1413 patients with bladder and 810 cases with renal cancer and 4702 healthy controls.

\section{Material}

\section{Patients}

This study includes 1413 unselected cases of urothelial bladder cancer (376 women and 1037 men) and 810 unselected kidney cancer (360 women and 450 men) diagnosed at the Urology Hospital in Szczecin between 1986 and 2018. A total of 1518 incident cases of bladder cancer and 869 kidney cancer were identified during the study period. Of these, 1413 patients with bladder and 810 with kidney cancer accepted the invitation to participate (93, 93\%). All patients had a histopathological diagnosis of cancer. All patients had a histopathological diagnosis of cancer. The mean age of diagnosis of bladder cancer patients was 68 years (range 13-91) and 62 (range 17-91) of kidney cancer. A family history was taken by the construction of family tree and the completion of a standardized questionnaire. A total of 45 patients with a family history of at least 1 bladder cancer in first or second degree relatives and 30 cases with a family history of at least 1 kidney cancer in first or second degree relatives were identified. Cigarette smoking was reported in 1045 (74\%) cases with bladder and 488 (60\%) kidney cancers. The vital status and the date of death of all of the cases were requested from the Polish Ministry of the Interior and Administration in February 2020, and were obtained in March 2020. In total we collected data of death of 729 (51\%) patients with bladder and 204 (25\%) kidney cancer. The study was approved by the Ethics Committee of Pomeranian Medical University in Szczecin.

\section{Controls}

The control group included 4702 cancer-free, populationbased, adults from (the genetically homogeneous population) of Poland. In order to estimate the frequency of the Polish founder mutations in the general population, fourth control groups were combined. The first control group were women age 24-84 years identified from the region of
Szczecin. These controls are described in detail elsewhere [21]. The second control group consisted of 1717 cancerfree females aged 32-72 years who participated in mammography screening at eight different centers across Poland: Kielce, Legnica, Olsztyn, Poznan, Szczecin, Swidnica, Torun, and Zielona Góra and who provided a blood sample for DNA analysis. The third group of women included 1036 patients age 20-94 years selected at random from computerized lists of patients at family practices located in the region of Opole. And the last fourth group included 990 women age 50-66 years who participated in a colonoscopy screening programme for colorectal cancer in Szczecin, Bialystok, and Łódz. The allele frequencies for all variants in our control group were not dependent on age and the prevalence estimates of mutations in all genes were similar in younger and in older controls.

\section{Methods}

DNA was isolated from 5 to $10 \mathrm{~mL}$ of peripheral blood. The two recurrent mutations of PALB2 (509_510delGA and 172_175delTTGT) were genotyped as described previously $[14,22]$. In brief, these variants were genotyped with a TaqMan assay (Life Technologies, Carlsbad, CA) using a LightCycler Real-Time PCR 480 System (Roche Life Science, Mannheim, Germany). Sanger direct sequencing was undertaken to confirm the presence of mutations, using a BigDye Terminator v3.1 Cycle Sequencing Kit (Life Technologies), according to the manufacturer's protocol. In all reaction sets, positive and negative controls (without DNA) were used.

\section{Statistical analysis Survival analysis}

We followed up PALB2 mutation carriers from the date of diagnosis until the date of death from any cause, or March 2020, if they were still alive. The median followup was 204 months. Due to a two variants of PALB2 mutations (509_510delGA and 172_175delTTGT) were not statistical significant among bladder and kidney cancer patients we did not perform survival analysis.

\section{Odds ratios}

The prevalence of each of the two PALB2 alleles was compared in cases and in controls, singly and in combination. Odds ratios were generated from two-by-two tables and statistical significance was assessed using the Fisher exact test where appropriate. The odds ratios were used as estimates of relative risk and additionally were adjusted for age, sex and pack-years of smoking by multiple logistic regression. 


\section{Ethical statement}

The study was performed in accordance with the principles of the Declaration of Helsinki. All patients and controls provided written informed consent.

\section{Results}

\section{Bladder cancer}

Bladder cancer cases and 4702 controls were successfully genotyped for the two PALB2 variants. Among bladder cancer cases the PALB2 mutations (two variants combined) were found in $0.35 \%$ of the patients and in $0.21 \%$ of the controls $(\mathrm{OR}=1.7 ; 95 \%$ CI $0.56-4.88 ; p=0.52)$ (Table 1). A PALB2 mutation (509_510delGA) was present in four $(0.3 \%)$ of 1413 cases with bladder cancer and in seven $(0.15 \%)$ of 4702 controls $(\mathrm{OR}=1.9 ; 95 \% \mathrm{CI}$ $0.55-6.51 ; p=0.5)$. A mutation 172_175delTTGT was detected in one patient with bladder cancer $(6.55 \%)$ and three $(0.06 \%)$ out of 4702 controls $(\mathrm{OR}=1.1 ; 95 \% \mathrm{CI}$ $0.11-10.7 ; p=0.9)$. In the group of 1037 men we observed three $(0.29 \%)$ mutations of 509_510delGA and among 376 womans were two $(0.53 \%)$ mutations of PALB2 gene one of each type. The information about smoking we collected from 1045 patients with bladder cancer including 123 (11.8\%) nonsmokers and 922 (88.2\%) smokers. We observed one PALB2 mutation in person who did not smoke $(0.8 \%)$ and four mutations among smokers $(0.4 \%)$. The frequency of PALB2 mutation was slights higher in non-smokers $(\mathrm{OR}=1.9 ; 95 \%$ CI $0.21-17 ; p=0.47)$. In 45 family cases with bladder cancer in first- and/or second-degree relatives we did not observed any of investigated mutations in gene PALB2. Three patients with bladder cancer and mutation in variant 509_510delGA died up to a year after diagnosis and one to March 2020 was still alive. Patient with mutation in 172_175delTTGT died half year after diagnosis of the bladder cancer.

\section{Kidney cancer}

The 810 kidney cancer cases and 4702 controls were successfully genotyped for the two PALB2 variants. In kidney cases PALB2 mutations (two variants combined) were found in $0.24 \%$ of the patients and in $0.21 \%$ of the controls $(\mathrm{OR}=1.2$; 95\% CI 0.25-5.13; $p=0.84)$ (Table 2). The PALB2 mutations (509_510delGA) were present in one $(0.1 \%)$ of 810 cases with kidney cancer and in seven (0.15\%) of 4702 controls $(\mathrm{OR}=0.8$; 95\% CI, $0.10-6.75$; $p=0.86)$. A mutation 172_175delTTGT was detected in one patient with kidney cancer $(0.1 \%)$ and three $(0.06 \%)$ out of 4702 controls $(\mathrm{OR}=1.9 ; 95 \% \mathrm{CI}, 0.20-18.6 ; p=$ 0.56). In the group of 450 men we observed two $(0.45 \%)$ mutations of PALB2 gene one of each type. The information about smoking we collected from 488 patients with kidney cancer including 190 (39\%) nonsmokers and 298 (61\%) smokers. The one mutation of variant 509 510delGA was observed in person who smoked less than 20 of pack years $(0.33 \%)$. We did not have information about smoking in patients with mutation 172 175delTTGT in PALB2 gene. In 30 family cases with kidney cancer in first- and/or second-degree relatives we did not observed any of investigated mutations in gene PALB2. The patient with kidney cancer and mutation in 172_175delTTGT died 3 years after kidney cancer of diagnosis but the patient with mutation in second investigated variant of gene PALB2 was still alive until March 2020.

\section{Discussion}

The results of our unselected cohort 1413 bladder, 810 kidney cancer cases and 4702 controls revealed no statistical significant, indicating that two mutations of PALB2 gene (509_510delGA and 172_175delTTGT) do not seem to play a major role in bladder or kidney cancer development. The PALB2 mutations combined are rare in the general population $(0.21 \%)$. In this study we found that mutations in PALB2 gene were seen in five $(0.35 \%)$ unselected cases of bladder cancer and two $(0.24 \%)$ unselected cases of kidney cancer. Due to low statistical power of the study $18.6 \%$ for bladder cancer and 5.2\% for kidney cancer our results need to be confirmed by larger multi-center study.

Table 1 Effect of PALB2 Mutations on Bladder Cancer Risk

\begin{tabular}{|c|c|c|c|c|}
\hline Mutation subjects & Number of carriers/total (frequency \%) & OR & $95 \% \mathrm{Cl}$ & $p$-value \\
\hline \multicolumn{5}{|l|}{ 509_510delGA } \\
\hline Controls & $7 / 4702(0.15)$ & 1.0 & & \\
\hline Cases & 4/1413 (0.3) & 1.9 & $0.55-6.51$ & 0.5 \\
\hline \multicolumn{5}{|l|}{ 172_175delTTGT } \\
\hline Controls & 3/4702 (0.06) & 1.0 & & \\
\hline Cases & $1 / 1413(6.55)$ & 1.1 & $0.11-10.7$ & 0.9 \\
\hline \multicolumn{5}{|l|}{ Any PALB2 mutation } \\
\hline Controls & $10 / 4702(0.21)$ & 1.0 & & \\
\hline Cases & $5 / 1413(0.35)$ & 1.7 & $0.56-4.88$ & 0.52 \\
\hline
\end{tabular}


Table 2 Effect of PALB2 Mutations on Kidney Cancer Risk

\begin{tabular}{|c|c|c|c|c|}
\hline Mutation subjects & Number of carriers/total (frequency \%) & OR & $95 \% \mathrm{Cl}$ & $p$-value \\
\hline \multicolumn{5}{|l|}{ 509_510delGA } \\
\hline Controls & $7 / 4702(0.15)$ & 1.0 & & \\
\hline Cases & $1 / 810(0.1)$ & 0.8 & $0.10-6.75$ & 0.86 \\
\hline \multicolumn{5}{|l|}{ 172_175delTTGT } \\
\hline Controls & 3/4702 (0.06) & 1.0 & & \\
\hline Cases & $1 / 810(0.1)$ & 1.9 & $0.20-18.6$ & 0.56 \\
\hline \multicolumn{5}{|l|}{ Any PALB2 mutation } \\
\hline Controls & 10/4702 (0.21) & 1.0 & & \\
\hline Cases & 2/810 (0.24) & 1.2 & $0.25-5.13$ & 0.84 \\
\hline
\end{tabular}

In the literature there are some studies of PALB2 in unselected bladder and kidney cancer cases but again they are based upon small study cohorts. Reid et al. have described bi-allelic mutations in PALB2 in seven families affected with Fanconi anemia and cancer in early childhood [12]. Although PALB2 mutations were less common overall and appreciated in only $0.6 \%$ of tumors tested a significant proportion of PALB2 mutations were found in bladder (1.49\%), breast (1.05\%) but no single mutation was found in kidney. Adank et al screened a random cohort of 47 Dutch Wilms tumor patients for germline mutations in PALB2 by DNA sequencing and Multiplex Ligation-dependent Probe Amplification and they did not identify any bi-allelic pathogenic mutations [23]. Heeke et al. tested 201 bladder and 199 kidney tumors. Thy found that frequency of gene PALB2 mutation was $1.49 \%$ in bladder cancer and $0 \%$ in kidney cancer tumors [24]. Lee Yap et al. found five somatic mutations of $P A L B 2$ gene in two cases of bladder cancer [25]. Lee Yap et al. also observed that in patients with mutations in DNA repair genes is longer recurrence-free survival. In this study we did not do multivariable analysis because the presence of a PALB2 (509_510delGA and 172_175delTTGT) mutations were not statistical significant among bladder and kidney cancer patients.

In summary we found no difference in the prevalence of recurrent PALB2 mutations between cases and healthy controls. Our results indicate that testing mutations 509_510delGA and 172_175delTTGT is unlikely to be relevant for the identification of individuals at risk of bladder or kidney cancer, at least in the Polish population.

\section{Acknowledgements}

We thank Anita Giermakowska for support in this study.

\section{Authors' contributions}

EZ-P - wrote the manuscript; EZ-P, WK, DK - carried out the molecular genetic studies; TW - performed the statistical analysis; CC, TD, MS, AL, MS, JT enrolled the patients into the study group; CC - conceived and designed the experiments; TD, $J$ - dcritically revised the manuscript and approved its final version. All authors read and approved the final version of the manuscript.

\section{Funding}

Not applicable.

Availability of data and materials

Availability of data and materials are include in manuscripts.

\section{Ethics approval and consent to participate}

The study was approved by Ethics Committee of the Pomeranian Medical University in Szczecin, Poland. All participants gave informed written consent prior blood donating.

\section{Consent for publication}

Not applicable.

\section{Competing interests}

$J \mathrm{~L}$ is CEO of Read-Gene S.A. The authors EZP, TD, MS, AL, MS, TW, JT, WK, DW, CC declare that they have no conflict of interest relevant to this article.

\section{Author details}

'Department of Genetics and Pathology, International Hereditary Cancer Center, Pomeranian Medical University in Szczecin, Unii Lubelskiej 1, 71-252 Szczecin, Poland. ${ }^{2}$ Departament of Urology and Urological Oncology, Pomeranian Medical University in Szczecin, Szczecin, Poland. ${ }^{3}$ Gdański Uniwerytet Medyczny Zakład Medycznej Diagnostyki Laboratoryjnej w Gdańsku, Gdańsk, Poland. ${ }^{4}$ Department of Pathology, The Children's Memorial Health Institute, Warsaw, Poland.

Received: 30 October 2020 Accepted: 21 December 2020 Published online: 08 January 2021

\section{References}

1. Mouw KW. DNA repair pathway alterations in bladder Cancer. Cancers (Basel). 2017;9(4):28. https://doi.org/10.3390/cancers9040028.

2. Warner EW, Yip SM, Chi KN, Wyatt AW. DNA repair defects in prostate cancer: impact for screening, prognostication and treatment. BJU Int. 2019; 123(5):769-76. https://doi.org/10.1111/bju.14576 Epub 2018 Oct 26.

3. Majidinia M, Yousefi B. DNA repair and damage pathways in breast cancer development and therapy. DNA Repair (Amst). 2017;54:22-9. https://doi.org/ 10.1016/j.dnarep.2017.03.009 Epub 2017 Apr 21.

4. Rimar KJ, Tran PT, Matulewicz RS, Hussain M, Meeks JJ. The emerging role of homologous recombination repair and PARP inhibitors in genitourinary malignancies. Cancer. 2017;123(11):1912-24. https://doi.org/10.1002/cncr. 30631 Epub 2017 Mar 21.

5. Hsieh P, Yamane K. DNA mismatch repair: molecular mechanism, cancer, and ageing. Mech Ageing Dev. 2008;129(7-8):391-407. https://doi.org/10. 1016/j.mad.2008.02.012 Epub 2008 Mar 4.

6. Hayashi K, Hishikawa A, Itoh H. DNA Damage Repair and DNA Methylation in the Kidney. Am J Nephrol. 2019;50(2):81-91. https://doi.org/10.1159/ 000501356 Epub 2019 Jun 26.

7. labal J, Ragone A, Lubinski J, et al. The incidence of pancreatic cancer in BRCA1 and BRCA2 mutation carriers. Br J Cancer. 2012;107:2005-9.

8. Polo SE, Jackson SP. Dynamics of DNA damage response proteins at DNA breaks:a focus on protein modifications. Genes Dev. 2011;25:409-33. 
9. Lupo B, Trusolino L. Inhibition of poly (ADP-ribosyl) ation in cancer: old and new paradigms revisited. Biochim Biophys Acta. 2014;1846(1):201-15. https://doi.org/10.1016/j.bbcan.2014.07.004 Epub 2014 Jul 12.

10. Nepomuceno TC, Gregorris G, Bastos de Oliveira FM, Suarez-Kurtz G, Montiero AN, Carvalho MA. The role of PALB2 in the DNA Damage Response and Cancer Predisposition. Int J Mol Sci. 2017;18(9):1886. https://doi.org/10.3390/ijms18091886.

11. Xia B, Sheng Q, Nakanishi K, Ohashi A, Wu J, et al. Control of BRCA2 cellular and clinical functions by a nuclear partner, PALB2. Mol Cell. 2006;22:719-29.

12. Reid $\mathrm{S}$, et al. Biallelic mutations in PALB2 cause Fanconi anemia subtype FA$\mathrm{N}$ and predispose to childhood cancer. Nat Genet. 2007;39:162-4. https://doi.org/10.1038/ng1947

13. Lener MR, Scott RJ, Kluźniak W, Baszuk P, Cybulski C, Wiechowska-Kozłowska A, Huzarski T, Byrski T, Kładny J, Pietrzak S, Soluch A, Jakubowska A, Lubiński J. Do founder mutations characteristic of some cancer sites also predispose to pancreatic cancer? Int J Cancer. 2016;139(3):601-6. https://doi.org/10. 1002/ijc.30116 Epub 2016 Apr 18.

14. Cybulski C, Kluźniak W, Huzarski T, Wokołorczyk D, Kashyap A, Jakubowska A, Szwiec M, Byrski T, Dębniak T, Górski B, Sopik V, Akbari MR, Sun P, Gronwald J, Narod SA, Lubiński J. Clinical outcomes in women with breast cancer and a PALB2 mutation: a prospective cohort analysis. Polish hereditary breast Cancer consortium. Lancet Oncol. 2015;16(6):638-44. https://doi.org/10. 1016/S1470-2045(15)70142-7 Epub 2015 May 7.

15. Norquist BM, Harrell MI, Brady MF, Walsh T, Lee MK, Gulsuner S, Bernards SS, Casadei S, Yi Q, Burger RA, Chan JK, Davidson SA, Mannel RS, Disilvestro PA, Lankes HA, Ramirez NC, King MC, Swisher EM, Birrer MJ. Inherited mutations in women with ovarian carcinoma. JAMA Oncol. 2016;2(4):482-90. https://doi.org/10.1001/jamaoncol.2015.5495.

16. Kanchi KL, Johnson K, Lu C, McLellan MD, Leiserson MD, Wendl MC, Zhang Q, Koboldt DC, Xie M, Kandoth C, McMichael JF, Wyczalkowski MA, Larson DE, Schmidt HK, Miller CA, Fulton RS, Spellman PT, Mardis ER, Druley TE, Graubert TA, Goodfellow PJ, Raphael BJ, Wilson RK, Ding L. Integrated analysis of germline and somatic variants in ovarian cancer. Nat Commun. 2014;5:3156. https://doi.org/10.1038/ncomms4156.

17. Xia $\mathrm{B}$, Dorsman $\mathrm{JC}$, Ameziane $\mathrm{N}$, et al. Fanconi anemia is associated with a defect in the BRCA2 partner PALB2. Nat Genet. 2007;39:159-61.

18. Erkko $\mathrm{H}$, Xia B, Nikkila J, et al. A recurrent mutation in PALB2 in Finnish cancer families. Nature. 2007;446:316-9.

19. Foulkes WD, Ghadirian P, Akbari MR, et al. Identification of a novel truncating PALB2 mutation and analysis of its contribution to early-onset breast cancer in French-Canadian women. Breast Cancer Res. 2007;9:83.

20. Dansonka-Mieszkowska A, Kluska A, Moes J, et al. A novel germline PALB2 deletion in Polish breast and ovarian cancer patients. BMC Med Genet. 2010;11:20.

21. Gronwald J, Raczyński A, Tarhoni M, et al. Population screening for cancer family syndromes in the West Pomeranian region of Poland Hered. Cancer Clin Pract. 2006;:56

22. Cybulski C, Lubinski J, Wokolorczyk D, et al. Mutations predisposing to breast cancer in 12 candidate genes in breast cancer patients from Poland. Clin Genet (2014). npublished online Nov 13.dx.doi.org/10.1111/cge.12524.

23. Adank MA, Segers $H$, van Mil $S E$, van Helsdingen $Y M$, Ameziane $N$, van den Ouweland AM, Wagner A, Meijers-Heijboer H, Kool M, de Kraker J, Waisfisz $\mathrm{Q}$, van den Heuvel-Eibrink MM. Fanconi anemia gene mutations are not involved in sporadic Wilms tumor. Pediatr Blood Cancer. 2010;55(4):742-4. https://doi.org/10.1002/pbc.22588.

24. Heeke AL, Pishvaian MJ, Lynce F, Xiu J, Brody JR, Chen WJ, Baker TM, Marshall JL. Prevalence of Homologous Recombination-Related Gene Mutations Across Multiple Cancer Types. Isaacs C JCO Precis Oncol. 2018; 2018. https://doi.org/10.1200/PO.17.00286 Epub 2018 Jul 23.

25. Yap KL, Kiyotani K, Tamura K, Antic T, Jang M, Montoya M, Campanile A, Yew PY, Ganshert C, Fujioka T, Steinberg GD, O'Donnell PH, Nakamura Y, Whole-exome sequencing of muscle-invasive bladder cancer identifies recurrent mutations of UNC5C and prognostic importance of DNA repair gene mutations on survival. Clin Cancer Res. 2014;20(24):6605-17. https://doi.org/10.1158/1078-0432.CCR-14-0257 Epub 2014 Oct 14

\section{Publisher's Note}

Springer Nature remains neutral with regard to jurisdictional claims in published maps and institutional affiliations.

Ready to submit your research? Choose BMC and benefit from:

- fast, convenient online submission

- thorough peer review by experienced researchers in your field

- rapid publication on acceptance

- support for research data, including large and complex data types

- gold Open Access which fosters wider collaboration and increased citations

- maximum visibility for your research: over $100 \mathrm{M}$ website views per year

At BMC, research is always in progress.

Learn more biomedcentral.com/submissions 